\title{
THE TERMS ARE CARRIED OUT IN THE FILING OF INTELLECTUAL PROPERTY TO GET A PATENT
}

\author{
EKA MEI RISTIANTI \\ 165100091 \\ Fakultas Komputer, 448757154 \\ ekameiristianti.student@umitra.ac.id
}

\begin{abstract}
The term "patent" we often hear used by the wider community, and even not uncommon in understand as equivalent of the term "intellectual property" itself. But behold, the patent is just one of the many forms of INTELLECTUAL PROPERTY protection. The patent is protection of intellectual COPYRIGHT for works that are technology, also known by the term invention, and the contain the solution/technical solution to the problem of the existing technology.

Patent invention can be a product or a process, as an example of combustion in the engine of a motor vehicle that aims to produce exhaust emissions that are environmentally friendly.,both the method and the process of how the burning is done, and the engine that implements the method and process of burning it, both of which can be patented as each process and product patent.
\end{abstract}

Patent rights are only granted to the first time submitting an application that at least has been completed with the minimum requirements for filing, so that it is entitled to get the filing date.Patents also are territorial, meaning that a patent is only valid in the country where the patent application is submitted and given. 


\section{A. INTRODUCTION}

The term "patent" we often hear used by the wider community, and even not uncommon in understand as equivalent of the term "intellectual property" itself. But behold, the patent is just one of the many forms of INTELLECTUAL PROPERTY protection. The patent is protection of intellectual COPYRIGHT for works that are technology, also known by the term invention, and the contain the solution/technical solution to the problem of the existing technology.

Patent invention can be a product or a process, as an example of combustion in the engine of a motor vehicle that aims to produce exhaust emissions that are environmentally friendly.,both the method and the process of how the burning is done, and the engine that implements the method and process of burning it, both of which can be patented as each process and product patent.

\section{Terms for intellectual works in order to be patentable}

Category a work of invention can be patented and based on certain characteristics. In other words, not all results could be patented. Work/invention that can be patented should be qualified in substantis. The following requirement:

1. the nature of the new

Intellectual works have never been publicized in advance, both published in any media. As for the steps that should be resized in order to obtain a patent, by filing a petition, will obtain the date of acceptance. If the intellectual works published before the date of acceptance, then the application could fail.

\section{Inventive nature}

The principle of obtaining INTELLECTUAL PROPERTY patents are inventive, or the ability to create, design something like 
never before. Patents are only granted on inventors who have a person skilled in the art.

\section{Applicative in nature}

The intent of the Applicative research results that are found can be done repeatedly. It can also mean having a kemanfatan level for the community. Getting the results of his discoveries used community-wide, indicating that his invention was successful as solutions to problems that arise. Intellectual works have terms that are consistent, do not easily changeable.

\section{The following example procedure for filing a patent}

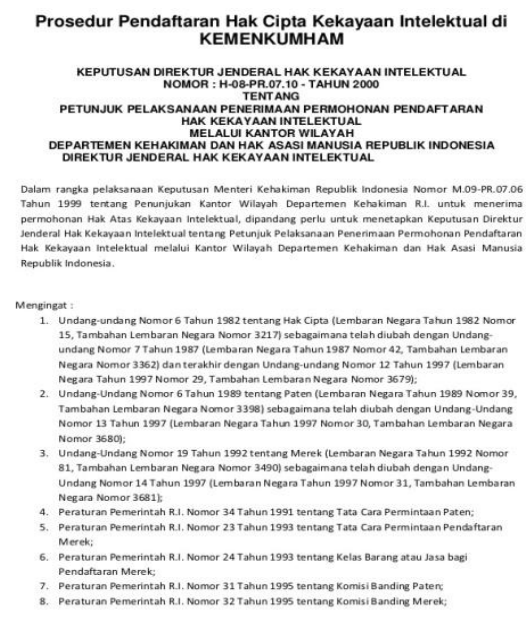

\section{The following notes to obtain patent rights}

The owner of the intellectual works referred to by the term inventor. Inventor's can be done individually and groups. Inventor's easier getting a patent for their invention of the results of intellectual work, while for outside the inventor's first obtained the transfer of rights, in writing, from the inventor.

If there are other parties that obtained the transfer of the rights of the inventor will head the patent for 20 tahum such an exclusive right shall become public domain. Public domain diperuntunkan for the general public, of course keep doing process permissions on patent holders.

Patent rights in INTELLECTUAL PROPERTY are territorial. In this case the patent rights only apply $\mathrm{d}$ inventor country apply for a patent. The filing is done by sending a letter to the direktoral General of intellectual property rights (DJHKI). If the inventor obtains patent rights in indonesia, then a patent obtained is not 
valid or does not have patent rights in other countries.

Inventor's obligation to obtain patent rights HAKI reserves the right to pay the annual fee. The cost of part of the cost of maintenance of the patent as of the last year of the period of protection. A patent will be lost if not legally paid for three consecutive years. The large maintenance costs of patents established pleh PNBP (Not State Tax Receipt) in the Ministry of Justice and human rights.

Financing charges consist of some costs i.e. costs pook and cost per claim. The payment period once every year, based on the same date as the first patent application.In other words, the deadline for payment falls on the same date of filing.

\section{Patent rights are Time Sensitive.}

Patents are granted on a first-time inventor filed a patent application. The time of the filing of the petition are crucial and time-sensitive. In other words, if there are two inventor has exactly the same intellectual work, then that will be recognized was the first inventor to apply.

Patent rights in INTELLECTUAL PROPERTY for those who already know, flocked to apply. Patent application fee of Rp. 750,000.00. Though they are actually still hesitate to verify it. Interestingly, there are some who do not ignore the cost of registration of patents for intellectual works not commercially. They still don't feel a loss, because acquiring patent rights more important than just profit economically. Remember, a patent cannot be patented again if it's been published.

\section{Intellectual works that cannot be patented}

The intellectual works that are aesthetic creations such as copyright and industrial designs are relatively easy to obtain a patent. Including the discovery of a method of computer programs, presentation of information found easier to obtain permission of the patent. However, there are also 
intellectual works that turned out not to be patented. The following explanation:

1. Intellectual Works is not opposed to regulation of intellectual property rights, which were not announced at the paper before applying.

2. intellectual bertentanagan did not work with legislation.

3. works of Hasl also contains religious morality is not opposed to race and interfere with public order.

4. Work intelektial not try in practice.

5. Intellectual Works not include methods and theory. For example methods of examination, treatment, treatment, surgery, and medications, including theory and mathematical formulas.

As powerful as any formula of resolving the problems, still cannot be patented.

\section{B. CONCLUSION}

From the explanation above, it can be concluded that a patent is one part of Intellectual Property Rights (IPR) which functions to protect a person's work . Intellectual works the assortment, which is starting technology (invention), research, art and much more. One example of the intellectual work of an invention can be patented can be product and process.

Terms for intellectual works in order to be patentable:

1. Are the new

2. Inventive nature

3. Applicative in nature

As for the intellectual work that cannot be patented:

1. Intellectual Works is not opposed to regulation of intellectual property rights.

2. intellectual bertentanagan did not work with legislation.

3. works of Hasl also contains religious morality is not opposed to race and interfere with public order.

4. Work intelektial not try in practice.

5. Intellectual Works not include methods and theory.

Patent rights are only granted to the first time submitting an application that at least has been completed with the minimum requirements for filing, so that it is entitled to get the filing 
date. Patents also are territorial, meaning that a patent is only valid in the country where the patent application is submitted and given.

\section{ACKNOWLEDGEMENT University Of Indonesia University Of Mitra Indonesia Telkom University University Of Mellbourne Saitama University}

\section{REFERENCE (Based ISO 690)}

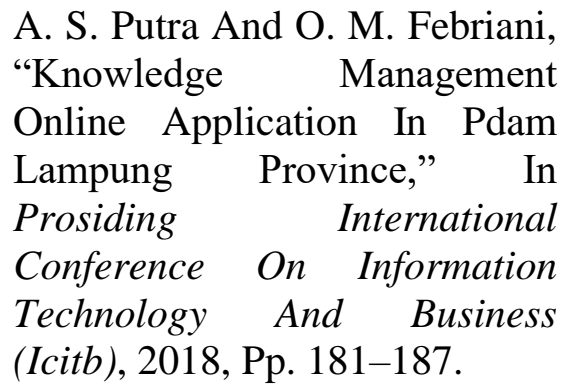

[2] A. S. Putra, O. M. Febriani, And B. Bachry, "Implementasi Genetic Fuzzy System Untuk Mengidentifikasi Hasil Curian Kendaraan Bermotor Di Polda Lampung," J. Sist. Inf. Dan Manaj. Basis Data, Vol. 1, No. 1, Pp. 21-30, 2018.

[3] O. M. Febriani And A. S. Putra, "Sistem Informasi Monitoring Inventori Barang Pada Balai Riset Standardisasi Industri Bandar Lampung," J. Inform., Vol. 13, No. 1, Pp. 90-98, 2014.

[4] Putra, Arie Setya. "2018 Artikel Struktur Data, Audit Dan Jaringan Komputer." (2018).
[5] Putra, A. S. (2018, July 17). Paperplain Fundamental Create Application With Borland Delphi 7.0 University Of Mitra Indonesia. Retrieved From Osf.Io/Pbrn9.

\section{E. REFERENCE (Based APA)}

Putra, A. S., Aryanti, D. R., \& Hartati, I. (2018, November). Metode SAW (Simple Additive Weighting) sebagai Sistem Pendukung Keputusan Guru Berprestasi (Studi Kasus: SMK Global Surya). In Prosiding Seminar Nasional Darmajaya (Vol. 1, No. 1, pp. 85-97).

Sari, D. P., Febriani, O. M., \& Putra, A. S. (2018, November). Perancangan Sistem Informasi SDM Berprestasi pada SD Global Surya. In Prosiding Seminar Nasional Darmajaya (Vol. 1, No. 1, pp. 289-294).

Putra, A. S. (2018). Paperplain: Execution Fundamental Create Application With Borland Delphi 7.0 University Of Mitra Indonesia.

Putra, A. S., Sukri, H., \& Zuhri, K. Sistem Monitoring Realtime Jaringan Irigasi Desa (JIDES) Dengan Konsep Jaringan Sensor Nirkabel. IJEIS (Indonesian Journal of Electronics and Instrumentation Systems), 8(2), 221232.

Darmawan, A., Yuliawati, D., Marcella, O., \& Firmandala, R. (2016). Sistem Absensi dan Pelaporan Berbasis Fingerprint dan SMS Gateway. EXPLORE, 7(1). 
Febriani, O. M., Wahyuni, T., \& Yusuf, S. (2017). DESIGN OF WEBSITE-BASED INFORMATION SYSTEM FOR EDOCUMENT

ADMINISTRASI IN THE
COMMUNITY SERVICE UNIT (A Case Study at Rajabasa District). INTERNATIONAL JOURNAL OF COMPUTERS \& TECHNOLOGY, 16(7), 7010-7020.

Febriani, O. M., \& Wahyuni, T. (2017, October). PERANCANGAN SISTEM E-DOCUMENT ADMINISTRASI LOGBOOK PENELITIAN PADA UNIT LAYANAN DI BANDAR LAMPUNG. In Prosiding Seminar Nasional Darmajaya (Vol. 1, No. 1, pp. 187-194).

Febriani, O. M., \& Permadi, A. B. (2017). Implementasi Sistem Aplikasi Data Bimbingan dan Pelanggaran Siswa pada Sekolah Menengah Atas di Lampung Tengah dengan Metode Analisis dan Desain Sistem Terdistribusi (SSAD). EXPERT, 7(1).

Febriani, O. M., \& Ambarwati, L. (2015). PERANCANGAN APLIKASI PENGOLAHAN DATA PENJUALAN UKM KELANTING KHAS TELO DESA SIDOHARJO KECAMATAN JATI AGUNG KABUPATEN LAMPUNG SELATAN. Jurnal Teknologi Informasi dan Bisnis Pengabdian Masyarakat Darmajaya, 1(1), 77-95.

Febriani, O. M. (2015). Rancang Bangun Aplikasi Ecommercemenggunakan Freewebstore pada UKM Kelanting di Desa Sidoharjo Lampung Selatan. Prosiding Sembistek 2014, 1(02), 446-458. 